\title{
Kırıkkale Üniversitesi Tıp Fakültesi Cerrahi Yoğun Bakım Ünitesinde 2008- 2009 Yıllarında İzole Edilen Mikroorganizmalar ve Antibiyotik Duyarlııkları
}

\author{
Microorganisms and Antibiotic Sussceptibility Patterns, Isolated from Surgical Intensive \\ Care Unit in Kırıkkale University School of Medicine in 2008-2009
}

\author{
Emine ECEMIŞ̧ ${ }^{1}$, Kenan ECEMIŞ̧ ${ }^{1}$, Sedat KAYGUSUZ ${ }^{1}$, Dilek KILIÇ ${ }^{1}$, Hilmi KOPUTAN ${ }^{2}$, \\ Ünase BÜYÜKKOÇAK ${ }^{2}$, Canan AĞALAR ${ }^{3}$ \\ ${ }^{1}$ Kırıkkale Üniversitesi Tıp Fakültesi Enfeksiyon Hastalıklarl ve Klinik Mikrobiyoloji AD., KIRIKKALE \\ ${ }^{2}$ Kırlkkale Üniversitesi Tip Fakültesi Anesteziyoloji ve Reanimasyon AD., KIRIKKALE \\ ${ }^{3}$ Istanbul Fatih Sultan Mehmet EAH, Enfeksiyon Hastalıklarl ve Klinik Mikrobiyoloji AD., ISTANBUL
}

\begin{abstract}
ÖZET
Antibiyotiklere dirençli mikroorganizmalar yoğun bakım ünitelerinde tedavide ciddi sorunlar ortaya çıkarmaktadır. Bu retrospektif çalışmada, cerrahi yoğun bakım ünitesinde (CYBÜ) 2008 ve 2009 y1llarında takip edilen hastalardan izole edilen mikroorganizmalar ve antibiyotik duyarlılıklarının karşılaştırılması amaçlanmıştır.

CYBÜ'de 2008- 2009 yılları arasında takip edilen sırasıyla 89 ve 112 yoğun bakım hastasından izole edilen bakterilerin disk difüzyon yöntemine göre duyarlılıkları belirlenmiştir.

Hastanemiz CYBÜ'de her iki yılda da en sık izole edilen Gram negatif bakteri Escherichia coli iken, en s1k izole edilen Gram pozitif bakteri ise koagülaz negatif stafilokoklar (KNS) olmuştur. Ayrıca izole edilen mikroorganizmalarda yıllara göre Acinetobacter spp. görülme oranı azalırken, direnç oranlarında ise genel bir artışın olduğu tespit edilmiştir.
\end{abstract}

ABSTRACT

Anahtar Kelimeler: Cerrahi Yoğun Bakım Ünitesi, antibiyotik duyarlılığı, yoğun bakım enfeksiyonları
Microorganisms resistant to antibiotics in intensive care units reveal serious problems in treatment. In this retrospective study, we aimed to compare the isolated microorganisms and antibiotic susceptibility patterns in Surgical Intensive Care Unit (SICU) patients who were followed in 2008 and 2009.

Antibiotic susceptibility patterns of bacteria isolated from 89 and 112 SICU patients followed in 2008-2009 respectively, were determined by the disk diffusion method.

In both years the most frequently isolated Gram-negative bacteria was Escherichia coli, while the most frequently isolated Gram-positive bacteria was coagulase-negative staphylococci (CoNS) in the SICU of our hospital. Also in isolated microorganisms the incidence of Acinetobacter spp decreased according to years but the resistance rates were found to be generally increased.

Keywords: Surgical Intensive Care Unit, antibiotic susceptibility, intensive care unit infections 


\section{GíRiş}

Yoğun bakım üniteleri (YBÜ) hastaneye yatan hastaların az bir kısmını barındırmasına karşın, hastane enfeksiyonlarının önemli bir kısmı burada görülmektedir. YBÜ’de nozokomiyal enfeksiyon sıklığı hastanenin diğer birimlerine göre beş ile on kat daha fazladır. Özellikle dirençli mikroorganizmaların etken olduğu hastane enfeksiyonlarının yol açtığı mortalite ve yüksek maliyetler önem taşımaktadır (13).

YBÜ'de yatan hastaların çoğu antibiyotik kullanmaktadır. Yoğun antibiyotik kullanımının hem Gram pozitif hem de Gram negatif mikroorganizmalarda yüksek direnç oluşumuna önemli katkısı vardır. Antibiyotiklere dirençli mikroorganizmaların neden olduğu enfeksiyonlar sadece morbidite ve mortaliteyi artırmakla kalmayıp aynı zamanda hastanede yatış süresinde uzama, maliyet ve çeşitli tıbbi komplikasyonlarda artışla da sonlanmaktadır.

YBÜ’lerde sıkça saptanan etkenlerin ve bunların duyarlı oldukları antibiyotiklerin bilinmesi nozokomiyal enfeksiyonlara yönelik etkili önlem ve tedavinin planlanmasında yarar sağlar (4).

$\mathrm{Bu}$ retrospektif çalışmada, Cerrahi Yoğun Bakım Ünitesi'nde (CYBÜ) 2008 ve 2009 yıllarında takip edilen hastalardan izole edilen mikroorganizmalar ve antibiyotik duyarlılıklarının karşılaştırılması amaçlanmıştır.

\section{GEREÇ VE YÖNTEM}

CYBÜ'de takip edilen 2008 yılındaki 89 hasta ile 2009 y1lındaki 112 hasta retrospektif olarak değerlendirilmiştir. Yatan hastalardan kültür için gönderilen örnekler \%5 koyun kanlı agar ve Eosin Metilen Blue agara (EMB) ekilmiş, $37^{\circ} \mathrm{C}$ 'de $18-24$ saat inkübasyon sonrası üreme olan örnekler tespit edilmiştir. Üreyen mikroorganizmalar tiplendirilerek
Kirby-Bauer disk difüzyon yöntemine göre antibiyogram duyarlılıkları belirlenmiş ve CLSI (Clinical and Laboratory Standards Institute) kriterlerine göre yorumlanmıştır. Seftazidim-seftazidim klavulanik asit ve sefotaksim-sefotaksim klavulanik asit diskleri arasındaki zon çapı farkı $5 \mathrm{~mm}$ ve üzeri olan suşlar genişlemiş spektrumlu beta laktamaz (GSBL) pozitif olarak yorumlanmıştır. Elde edilen mikroorganizmaların 2008 ve 2009 yıllarındaki antibiyotik direnç profilleri karşılaştırılmıştır.

\section{BULGULAR}

Hastalardan izole edilen mikroorganizmalardan en s1k görülenler Escherichia coli, Acinetobacter spp. koagülaz negatif stafilokoklar (KNS) idi.

Elde edilen Gram pozitif ve negatif bakterilerin dağılımı Tablo 1'de gösterilmiştir.

Tablo 1: İzole edilen mikroorganizmaların yıllara göre dağılımı

\begin{tabular}{lcc}
\hline & $2008 \mathrm{y} 1 \mathrm{ll}$ & 2009 y1lı \\
\cline { 2 - 3 } & $\mathrm{n}(\%)$ & $\mathrm{n}(\%)$ \\
\hline Escherichia coli & $27(28.72)$ & $33(28.20)$ \\
Acinetobacter spp. & $20(21.27)$ & $10(8.54)$ \\
KNS & $17(18.05)$ & $16(13.67)$ \\
Candida albicans & $8(8.51)$ & $10(8.54)$ \\
Pseudomonas spp. & $7(7.44)$ & $10(8.54)$ \\
Enterococ spp. & $3(3.19)$ & $7(5.98)$ \\
Staphylococcus aureus & $3(3.19)$ & $6(5.12)$ \\
\hline
\end{tabular}

Duyarlılık sonuçlarında; birinci yılda izole edilen Acinetobacter spp. 'nin \%30’u karbapenemlere dirençli iken, ikinci y1lda bu oran \%60 bulunmuştur. Pseudomonas spp.'de ise ilk y1lda karbapenemlere direnç $\% 0$ iken, ikinci yılda bu oran \%40’a 
yükselmiştir. E. coli suşlarının \%40,8'i ilk yılda kinolonlara dirençli iken, ikinci yılda aynı oran \%57,6'ya yükselmiştir. Aynı suşlarda GSBL pozitifliği y1llara göre $\% 14,8$ ve $\% 15.15$ olarak saptanmıştır.

Tablo 2: Acinetobacter ve Pseudomonas spp.'nin karbapenem direncinin yıllara göre dağılımı

\begin{tabular}{lcc}
\hline & \multicolumn{2}{c}{ Karbapenem Direnci (\%) } \\
\cline { 2 - 3 } & $2008 \mathrm{y} 1 \mathrm{l}_{1}$ & $2009 \mathrm{y} \mathrm{ll}_{1}$ \\
\hline Acinetobacter spp. & 30 & 60 \\
Pseudomonas spp. & 0 & 40 \\
\hline
\end{tabular}

Gram pozitif bakterilerde ise tüm enterokok suşları her iki yılda da vankomisine hassas bulunmuştur. S. aureus suşlarında metisilin direnci ilk yıl \%100 iken, 2. yılda bu oran \%66,6 olarak tespit edilmiştir. KNS suşlarında yıllara göre metisilin direnci sirasıyla $\% 70,6$ ve $\% 87,5$ olarak saptanmıştır.

\section{TARTIŞMA}

Yoğun bakım hastalarının yaklaşık \%80'inde 48-72 saat içinde hastane enfeksiyonu ortaya çıktığı, bu enfeksiyonlarda etken olan mikroorganizmaların ve bunların antibiyotik duyarlılık profillerinin zaman içinde ve bölgesel olarak farklılıklar gösterebildiği bilinmektedir (5).

Yoğun bakım ünitelerinde enfeksiyonun geliştiği vücut bölgesine göre farklılık saptanmakla birlikte Esen ve Leblebicioğlu'nun çalışmasında en sık saptanan etkenler $P$. aeruginosa $(\% 20,8)$, S. aureus $(\% 18,2)$, Acinetobacter spp. (\%18.2) ve Klebsiella spp. (\%16.1) olmuştur (6). İnan ve ark.'nın gerçekleştirdikleri çalışmada da ilk sıraları $P$. aeruginosa ve Acinetobacter spp. oluşturmak üzere yoğun bakımda gelişen enfeksiyonların \%65'inde Gram negatif bakterilerin etken olduğu saptanmıştır (7). Çetin ve ark. YBÜ’lerde izole edilen etkenleri araştırdıkları çalışmalarında, değerlendirilen toplam 565 etkenin 276 $(\% 48,9)$ 'sı Gram pozitif, 243 (\%43)'ü Gram negatif bakteri iken, $46(\% 8,1)$ 's1 mantar olarak tespit edilmiştir. En sık izole edilen etkenler Gram pozitif bakteriler içerisinde KNS (194) ve S. aureus (45); Gram negatif bakterilerden ise A. baumannii (56) ve $E$. coli (53) olarak saptanmıştır (8). Çalışmamızda Gram negatif basiller en sık görülen etkenler olmuştur (Tablo1).

Stafilokoklarda metisiline direnç oranlarının arttığg, Gram negatif basillerde ise geniş spektrumlu betalaktam antibiyotiklere ve karbapenemlere duyarlılığın azaldığ 1 bildirilmiştir (9). Nozokomiyal MRSA oranı genel olarak artış göstermekle birlikte, MRSA suşlarının hastanelere göre dağılımı homojen değildir. Yatak kapasitesi ile MRSA suşlarının sıklığının orantılı olduğu saptanmıştır. Amerika'da yapılan bir araştırmada 200'den az yatak kapasiteli hastanelerde $S$. aureus suşlarında metisilin direnç oranı \%14,9 iken, 500 ve daha çok yatak kapasiteli hastanelerde ise belirgin bir artış göstererek \%38,3'e çıktığı bildirilmiştir $(10,11)$.

Çalışmamızda, S. aureus suşlarında metisilin direnci ilk y1l \%100 iken, 2. y1lda bu oran \%66,6 olarak tespit edilmiştir. Hastanemizin yoğun bakım yatak kapasitesinin az oluşu, daha az komplike hasta popülasyonu olması bu sonuçları desteklemektedir. KNS suşlarında ise yıllara göre metisilin direnci sırasıyla \%70,6 ve \%87,5 olarak saptanmıştır.

Gram negatif bakterilerde, birinci yılda izole edilen Acinetobacter spp. 'nin \%30'u karbapenemlere dirençli iken, ikinci yılda bu oran \%60'a yükselmiştir. Pseudomonas spp.'de ise oranlar sirasiyla $\% 0$ ve $\% 40$ olarak bulunmuştur.

Namıduru ve ark. CYBÜ'de izole edilen etkenleri araştırdıkları çalışmalarında, \%68,4 oranında Gram negatif, \%31,5 oranında Gram pozitif bakteri izole etmişler, en sık izole edilen bakteri olarak $P$. aeruginosa'yı $(\% 34,5)$ bildirmişlerdir. Yazarlar bu 
bakteriyi sırasıly $S$. aureus $(\% 31,5)$ ve A. baumannii (\%22)'nin izlediğini bildirmişlerdir. $\mathrm{Bu}$ araştırmada Gram negatif izolatlara karşı en etkili bulunan antibiyotikler karbapenemler (\%76) ve levofloksasin $(\% 70)$ olarak tespit edilmiştir. S. aureus suşlarında ise metisilin direnci $\% 82$ bildirilmiştir (12).

Küçükateş ve ark. KNS'lerin yoğun bakım enfeksiyon etkenleri arasında ilk sırada olduğunu bunu Acinetobacter spp., Pseudomonas spp., K. pneumoniae ve $P$. aeruginosa'nın takip ettiğini bildirmişlerdir. Gram negatif çomaklar için karbapenemler ve siprofloksasin en duyarlı bulunmuştur (5). Özden ve ark YBÜ'lerde yatan hastalarda gelişen enfeksiyonlarda, Gram pozitif bakterilerin \%40, Gram negatif bakterilerin ise $\% 60$ oranında izole edildiğini bildirmiş, Gram pozitif bakterilerin \%48'inin S. aureus, \%45'inin KNS; Gram negatif bakterilerden ise en s1k izole edilen suşların $P$. aeruginosa ve Acinetobacter spp. olduğunu belirtmiştir. Gram negatif bakterilerin en duyarlı olduğu antibiyotiklerin karbapenemler olduğunu, S. aureus ve KNS'de metisilin direncinin sırasıly $\% 69,8$ ve $\% 84,8$ olarak saptandığını bildirmişlerdir (13).

Çalışmamızda, hastanemiz CYBÜ'de her iki yılda da en sık izole edilen Gram negatif bakteri E. coli iken, en s1k izole edilen Gram pozitif bakteri ise KNS olmuştur. Ayrıca izole edilen mikroorganizmalarda yıllara göre Acinetobacter spp. görülme oranı azalırken, direnç oranlarında ise artış olduğu tespit edilmiştir. İzole edilen mikroorganizmalarda yıllara göre Acinetobacter spp. görülme oranı azalırken, direnç oranlarında ise artış olduğu tespit edilmiştir. Hastanemizde 2008 yılında antibiyotik kullanım oranları 3. kuşak sefalosporinler için \%42,5, karbapenemler için \%30, glikopeptitler için \%21, kinolonlar için \%5,6 iken, 2009 y1linda bu oranlar sirasiyla $\% 52,5, \% 30,5, \% 9$ ve $\% 4,8$ olarak tespit edilmiştir. Enfeksiyon görülme oranları, etken dağılımları çok dinamik bir süreç olup, hastanelerde veya birimlerde kullanılan antibiyotiklerin kullanım oranları da bu süreci doğrudan etkileyebilmektedir. $\mathrm{Bu}$ nedenle hastanede kullanılan antibiyotikler, yıllara göre duyarlı1ık oranlarını etkileyebilmektedir.

Sonuç olarak, üreyen bakteriler ve direnç oranları bu ünitelerde ampirik antibiyotik tedavilerinin güçlüğünü buna bağlı olarak da aktif izlem ve önleyici tedbirlerin arttırılması gerekliliğini öne çıkarmaktadır. Etkili enfeksiyon kontrol önlemleri ile hastane enfeksiyonlarını \%20-30 oranında önleyebilmek mümkündür $(14,15)$.

Her merkezin kendi yoğun bakım ünitesi etkenlerini ve bu etkenlerin antibiyotik duyarlılık profilini saptaması ve bunu periyodik olarak yayınlaması nozokomiyal enfeksiyonların kontrolünde en önemli adımları oluşturacaktır.

\section{KAYNAKLAR}

1. Arman D. Yoğun bakım enfeksiyonlarının önemi ve epidemiyolojisi. Yoğun Bakım Dergisi. 2006; 6: $5-7$.

2. Sümerkan B. Yoğun Bakım Ünitesinde Gramnegatif mikroorganizmalar ve direnç sorunu. Yoğun Bakım Dergisi. 2003; 3: 129-34.

3. Ok G, Gazi H, Tok D, Erbüyün K. Celal Bayar Üniversitesi Anestezi Yoğun Bakım Ünitesi'nde hastane infeksiyonlarının sürveyansı. Yoğun Bakım Dergisi. 2007; 7(4): 452-57.

4. Spencer RC. Epidemiology of infection in ICUs. Intensive Care Med. 1994; 20 (Suppl 4): 2-6.

5. Küçükateş E, Kocazeybek B. İstanbul Üniversitesi Kardiyoloji Enstitüsü yoğun bakım ünitelerinde yatan hastalardan izole edilen bakteriler ve antibiyotik duyarlılıkları. Türk Mikrobiyol Cem Derg. 2001; 31: 19-22. 
6. Esen Ş, Leblebicioğlu H. Prevalence of nosocomial infections at intensive care units in Turkey: a multicentre 1-day point prevalence study, Scand J Infect Dis. 2004; 36(2): 144-48.

7. İnan $\mathrm{D}$, Saba $\mathrm{R}$, Keskin $\mathrm{S}$. Akdeniz Üniversitesi hastanesi yoğun bakım ünitelerinde hastane infeksiyonları sürveyansı: alet kullanım ve alet ilişkili infeksiyon oranları, Hastane İnfeksiyon Derg. 2004; 8(1): 50-6.

8. Çetin E, Kaya S, Pakbaş İ, Demirci M. Yoğun Bakım Ünitelerinde Yatan Hastalardan İzole Edilen Mikroorganizmalar ve Antibiyotik Duyarlılıkları. İnönü Üniversitesi Tıp Fakültesi Dergisi. 2007; 14(2): 69-73.

9. Köseoğlu Eser Ö, Kocagöz S, Ergin A, Altun B, Hasçelik G. Yoğun bakım ünitelerinde infeksiyon etkeni olan gram negatif basillerin değerlendirilmesi. İnfeksiyon Dergisi. 2005; 19(1): 75-80.

10. Panililio AL, Culver DH, Gaynes RP. Methicillinresistant Staphylococcus aureus in U.S. hospitals, 1975-1991. Infect Control Hosp Epidemiol. 1992; 13: 582-86.
11. Thornsberry C. Epidemiology of staphylococcal infections-a USA Perspective. J Chemother. 1994; 6 (Suppl 2): 61-65.

12. Namıduru M, Karaoğlan İ, Göksu S, Dikensoy Ö, Karaoğlan M. Cerrahi yoğun bakım ünitesinde hastane infeksiyonu etkeni olan bakteriler ve antibiyotiklere direnç durumları. İnfeksiyon Dergisi. 2003; 17(1): 39-44.

13. Özden M, Demirdağ K, Kalkan A, Kılıç SS. Yoğun bakım ünitelerinde izlenen ve hastane infeksiyonu gelişen olgulardan izole edilen bakterilerin sıklığı ve antibiyotiklere karşı direnç durumları. İnfeksiyon Dergisi. 2003; 17(2): 179-83.

14. Grundmann H, Barwolff S, Tami A. How many infections are caused by patient-to-patient transmission in intensive care units? Crit Care Med. 2005; 33(5): 946-51.

15. Harbarth S, Sax H, Gastmeier P. The preventable proportion of nosocomial infections: an overview of published reports. J Hosp Infect. 2003; 54(4): 258 66. 